https://doi.org/10.18485/iipe_euchanges.2021.ch18

\title{
THE PROBLEM OF REGIONAL SEPARATISM AS A FACTOR OF DESTABILISATION IN SPAIN
}

\begin{abstract}
Rastislav KAZANSKY ${ }^{1}$
Abstract: The contribution discusses the separatist tendencies of selected regions in Spain and their impact on the state's stability. The separatist tendencies have been present in Spain for a long time, and they are disrupting its political and economic stability. The main aim of this paper is to determine the causes of the origin and development of Basque and Catalan separatist tendencies and to describe their impact on the political and economic stability of Spain. To accomplish this aim, we used various methods such as description, region analysis and comparison. We also formed a hypothesis that the right of peoples to self-determination is a more legitimate argument in the case of Catalan separatism than in the case of Basque separatism, which can be confirmed. After the analysis, we concluded that the main aim was fulfilled. Moreover, it offers a development prognosis concerning separatist tendencies of the abovementioned regions.

Keywords: separatism, destabilisation, self-determination, the Basque country, Catalonia.
\end{abstract}

\section{THE THEORETICAL FRAMEWORK OF SEPARATISM RESEARCH}

Separatism forms the basis of our work and, therefore, we consider it important to bring several different definitions of this term given by several experts from the Slovak and foreign academic community.

The word separatism comes from the Latin word separare - to pull apart, separation, detachment. This phenomenon has accompanied humanity since its inception, and history offers a large number of tendencies of wars and conflicts among separatists. However, separatism is not just a matter of

${ }^{1}$ Associate Professor, Faculty of Political Science and International Relations of UMB, Banská Bystrica. E-mail: rastislav.kazansky@umb.sk 
the past. It is a phenomenon present in the 21st century throughout the world. Separatism arises when members of linguistic, ethnic, national, or religious groups feel that their degree of representation by political elites is insufficient, as well as the degree of autonomy of their territory created by administrative boundaries (Ištok, 2003).

According to Ištok and the team of authors, separatism, in the sense we know it today, appeared in Europe around the middle of the 19th century. Even then, it was associated with a new social phenomenon - nationalism (Čajka et al., 2010). We will also address this concept in the first chapter of the work. In Political Geography, the above-mentioned team of renowned Slovak academics defines separatism as 'a movement operating to separate a part of the territory and its population from a certain territory, either with the intention of creating a new state or joining a neighbouring state' (Čajka et al., 2010, p. 170). Separation is thus a process that is contrary to the primary goal of each state - to preserve its own territorial integrity. At the same time, it is contrary to the internal sovereignty of the state. This phenomenon cannot be removed from the reality of international relations by any law. At present, according to Barr, separation is the only way to create a new state (Baar, 2002, p. 23). It leads to the separation and independence of a certain territory, which differs in some way from the rest of the state, and the creation of a new independent state. In this context, Ivančík and Nečas argue that state separatism expresses the separation of a smaller part from the whole or the recognition of the autonomous rights of the national minority in the state (2012, p. 328).

The Cambridge Dictionary states that separatism is 'the belief held by people of a particular race, religion, or other group within a country that they should be independent and have their own government or in some way live apart from other people' (Cambridge Dictionary, n.d.). However, we consider this definition to be unprofessional and not entirely accurate. It does not mention the state's territory, only a group of people. The mere conviction of a group of people does not automatically mean a real separation of the territory in which they live from the rest of the state.

Another definition of separatism is offered by Červenáková (2013) in her rigorous work. It draws on Otto's General Encyclopaedia, which defines separatism as 'an effort to seize part of the state's territory, usually by its population, usually to unite divided populations united by a common ethnic, national and religious identity'. It is often accompanied by an effort to annex a part of the territory of one state to a neighbouring state' (Červenáková, 2013, p. 24). 
In his article Ryabinin used the Political Science Encyclopaedic Dictionary, which describes separatism as a movement for the territorial secession of a part of the territory to create a new state or achieve a degree of autonomy in areas such as language, religion or national issues (2017, p. 6). We consider this definition to be sufficiently relevant. It also brings a new perspective on separatism, and this is the aforementioned degree of autonomy. It is important to realize that separatism does not necessarily result in a real separation of a part of the state's territory from the rest. It may also be related to the requirement to achieve a higher degree of autonomy, but this is linked to the right of nations to self-determination. This law is closely linked to international law. The issue of separatism and the right of nations to self-determination from an international legal point of view will be addressed in the next subchapter.

Another slightly different definition comes from the American professor of sociology Schaeffer. He writes that separatism, in general, is a process of dividing an existing state and creating a successor state in the same territory. It is mainly the disintegration of the nation-state. He also states that the term secession may be synonymous with this term. Art Nouveau can be defined as the disintegration of a nation-state and the emergence of successor states on its territory. It is, therefore, the emergence of new subjects of law (Schaeffer, 2008). Giertl (2012) mentions secession in the context of the unilateral separation of a part of the territory of the state and the declaration of independence in that part of the territory. The Supreme Court of Canada has ruled on the issue of Art Nouveau that only colonial-dominated states that are in this way oppressed, and where dialogue on the internal realization of the right to self-determination is not possible in the future, have the right to Art Nouveau exploited. Thus, if a minority nation is represented in a state and is not discriminated against, the right to internal self-determination is therefore respected, and the nation has no right to demand the creation of its own state unit and thus violate the principle of territorial integrity (Giertl, 2012, p.17). However, international law does not support Art Nouveau because it is not in line with its basic principles (Rosenberg, 1997).

In the second half of the 19th century, small states separated from the increasingly weakening Ottoman Empire. This separatism was considered legitimate because it was a matter of national liberation struggles against Turkish colonialism ambitions. The period after the First World War was characterized by the fact that in Europe were created several states, whose borders did not correspond to the borders of the nations. This fact is also 
confirmed by the emergence of multinational states, such as Czechoslovakia, the Union of Soviet Socialist Republics, or the Kingdom of Serbs, Croats and Slovenes, which was renamed Yugoslavia in 1929 (Hruboň, 2020, pp. 84-86, $100)$. In the second half of the 20th century, new states emerged mostly in the process of decolonisation and also in situations of dissolution or splitting up. The only real separation from a state that has existed for at least 10 years has been the secession of Bangladesh from Pakistan. After the war, the victorious powers signed an agreement in Yalta, which dealt, among other things, with the post-war organization of Europe and the immutability of borders. As the number of states whose colonial borders did not represent national borders grew, so did the number of separatist movements. At present, they manifest themselves mostly in armed conflicts with the state power, but this is not the rule (Mesárová, 2012).

In the 20th century, in the process of decolonisation, new successor nation-states emerged in the world. In some cases, the leaders of these newly created states also wanted to conquer foreign territories that did not belong to them. The means to achieve such a goal were invasions and annexations. Such endeavours were never in line with international law. The pretext for the territorial expansion of these newly formed states was to unite the new nation into one state. Therefore, Israel launched the occupation of Palestine and Indonesia annexed the western part of the island of New Guinea and later East Timor (Schaeffer, 2008). ${ }^{2}$

Most of the examples of separatism mentioned were marked by prolonged armed struggles. The demands of separatist movements are generally similar and generally concern unresolved economic, social or national issues. The declaration of a territory as a new independent state was preceded either by the occupation of the territory by separatist troops or by the long-term control and administration of the territory without the interference of the central power. An example from practice regarding the second of the mentioned methods is the case of the Republic of Somaliland (Čajka et al., 2010).

An interesting view of separatism is provided by Boyle and Englebert, who define separatism as the process of forming a state preceded by tyranny and driven by the shared memories of the past $(2006, \mathrm{p}$. 3). This definition deviates from the more traditional definitions already mentioned. However,

\footnotetext{
${ }^{2}$ The establishment of the Israeli state ensued following the UN partitioning plan for Palestine and enjoyed international support. On the other hand, the Indonesian invasion of East Timor represents a different example.
} 
it offers an insight into separatism separate from nationalism, ethnic and religious elements.

The concept of separatism is also related to the concept of irredentism. Irredentism is a national movement whose goal is to connect a territory with a national minority to a state whose nationality is a given minority (Lněnička, 2011). It can also be defined as an attempt to tear off a certain part of the state territory in order to annex it to another state. Irredentism comes from the Latin words terra irredenta - unredeemed land. ${ }^{3}$ It began to appear in Europe in the second half of the 19th century and is considered a specific form of separatism (Baar, 2002).

Separatism can be based on various integral parts - cultural, religious, economic, ideological, ethnic, or even civilizational. In terms of the degree of activity, separatism can be active or mild. We speak of active separatism when an ethnic group actively supports the idea of Art Nouveau. In turn, we speak of moderation or mild separatism when an ethnic group demands only the status of autonomy, or when an ethnic group expresses dissatisfaction with its position in the state but has no demands to change that status. Other types of separatism result from such a perception, such as open and closed separatism. We speak of open separatism when an ethnic group openly expresses its demands for separation from the state (Baar, 2002, p. 65). Closed separatism, on the other hand, involves strictly prohibiting the government from discussing the possibility of separation (Ryabinin, 2017).

External factors influencing the strengthening of separatist processes in the state include the presence of neighbouring states or powers interested in weakening or even collapsing the state. At the same time, the aim of such action by states is to improve their own position in the region or expand their territory if they share a border with the separatist territory. According to Ryabinin (2017), this kind of separatism is visible and foreseeable in the post-Soviet space (an example is Donbas in Ukraine).

External factors have two different manifestations, two forms - soft and hard support. We consider military invasion as hard support, and it could occur in the following situations:

- If the region is supplied with ammunition;

${ }^{3}$ Unredeemed Italy, Italian-speaking territory not incorporated in Italy. In 1877 the Italian politician Matteo Renato Imbriani invented the new term 'terre irredente' ('unredeemed lands'). 
- Intervention by peacekeepers to bring a solution to the conflict, but taking into account the interests of either the rebel region or the state government, and

- Implementation of humanitarian intervention, which presupposes participation in the struggle on the part of the insurgent region (Ryabinin, 2017).

Soft support of external factors can be further divided into subtle active and subtle passive support. Subtle passive support is reflected in the existence of a neighbouring state with an ethnically close population. At the same time, there is an effort by this neighbouring state to unite nations into one state. On the other hand, subtle active support manifests itself as follows (Ryabinin, 2017):

- Cost-effective activities (financing of the fight, financing of nongovernmental organizations);

- Technically (arms supply);

- Humanitarian activities (creating links with ethically close people in the field of culture, education and science, financing educational programs, etc.);

- Support for the rebel region or bodies in international organizations, e.g., in the UN, OSCE;

- Construction of religious buildings, and

- Influencing public opinion (the negative portrayal of the insurgent region or state authorities).

In his article, Ryabinin describes five stages in the development of separatism: the introduction of identity; ban on language, culture and history; criminal prosecution; absorption of an ethnic group by a titular group, and genocide (2017, pp. 6-7).

\section{SYSTEM OF AUTONOMOUS COMMUNITIES}

Spain is characterized by a high degree of decentralisation of power. It is one of the most decentralised states in Europe. The decentralised organization of Spain has contributed to the development of democracy, to the economic growth of the state, and also to the improvement of the social system. The high degree of autonomy of individual territorial-administrative units is logically related to decentralisation. Spain is composed of 17 territorial units, which are called Comunidades Autónomas in Spanish, meaning the 
Autonomous Communities (Ištok, 2003). At the same time, the terms autonomous region and autonomous regions, which are synonymous, are also used. Besides, two regions located in North Africa - Ceuta and Melilla - are under the Spanish administration. These provinces do not have the status of an autonomous community but an autonomous city (ciudad autónoma) (Chalupa, 2009). The individual Spanish autonomous regions are separated by the so-called right boundaries, self-governing bodies. They define territorial-administrative units. Administrative boundaries can separate territories that differ in linguistic, ethnic, nationality, or religious terms (Ištok, 2003, p. 97).

These are national borders that have been set by the state, or by the state in cooperation with a certain degree of autonomy. In the process of creating the right borders in a heterogeneous state, it is important that these borders respect the linguistic, ethnic, national, or religious distribution of the population. If such boundaries were not set correctly and did not respect these factors, they could become a source of national conflict. On the other hand, even the administrative borders that respect the composition and distribution of the population can lead to distortions of national stability. Such a situation can occur if the individual administrations are fully accorded a high degree of autonomy, which can lead to the separatist tendencies of homogeneous territories within one heterogeneous state (Ištok, 2003, p. 98).

The term autonomy comes from the Greek word autónomos, which means to follow one's own laws. Political autonomy means that a certain political entity has a high degree of self-government. Most cities or regions have political autonomy. Autonomy does not represent absolute political independence or sovereignty. It represents a certain degree of freedom in the administration of a given territory transferred from the state to the city or region (Žaloudek, 2004, p. 23).

The system of Spanish autonomous communities cannot be identified with the territorial division in Spain or with the system of territorial selfgovernment from other unitary states. ${ }^{4}$ Spain offers a completely original way of decentralising state power. López Guerra and the team of authors (2010) used the words of the Spanish Constitutional Tribunal to describe the communities. They described the Autonomous Communities as public corporations that have a territorial basis as well as a political nature (López

${ }^{4}$ On the other hand, it can be compared with Italian regionalism. 
Guerra et al., 2010). In addition to the autonomous communities, the territorial division of the state includes the so-called provinces and municipalities (in Spanish privicias a municipios).

The process of creating a system of autonomous communities was relatively complex. The space for its rebound in Spain was made after the death of General Francisco Franco in 1975. After the end of Franco's dictatorship, the power was decentralised, and Spain began to transform into a democratic state. The system of autonomous regions was created by the Constitution of Spain in 1978, which is still in force today. Although the establishment of specific autonomous regions is not mentioned in the Constitution, space is provided for their establishment. Article 2 of the Constitution (1978) 'guarantees the right to autonomy of nationalities and regions...'. Articles 143-158 deal with the organization, competences, funding, bodies, and control of their activities (Domin, 2013, p. 42). Under Article 143 of the 1978 Constitution, several areas have been granted the status of a historical community. This was particularly true of the areas in the north of Spain, namely Catalonia, the Basque Country, Galicia and the southern part of Spain, Andalusia. Due to their position, these four areas had the opportunity to achieve a higher degree of autonomy more quickly, in the so-called first wave of decentralisation. In addition, they enjoyed various privileges. In the referendums on the establishment of the Autonomous Community, the will of only two-thirds of the majority of eligible voters was sufficient in these regions, while in thirteen other regions the will of three-fourths of the majority of eligible voters was required (Rosenberg, 1997, p. 27).

During the 20th century, Galicia, the Basque Country and Catalonia demanded the fulfilment of the right to autonomy and independent domestic political management of their territory. The establishment of the Second Republic in 1931 provided a suitable opportunity for the decentralisation of power. The Spanish Constitution of 1931 introduced a system of autonomous regions in the state. The reasons for the establishment of autonomous communities were stated directly in the Constitution. The common history of individual regions or the common economy is mentioned (Rosenberg, 1997, p. 27).

The basic and founding document of any Autonomous Community is the Statute of Autonomy (hereinafter 'the Statute'), which must be approved by the Spanish Parliament. However, the establishment of such a document also requires the will of the people expressed in a referendum in each autonomous region separately (Rosenberg, 1997). Article 147 (2) of the 
Constitution lays down the minimum substantive conditions of the Statute. Each statute must contain the official designation of the Autonomous Community, define its territory, regulate the designation, organization and seat of the Community institutions and present a calculation of the competences that the Community assumes from the central government (the framework is given by the Constitution). Of course, the statutes contain much broader information than just the minimum mentioned (Domin, 2013, p. 43). Such a process created only Catalan autonomy during the Second Republic (1931-1939). Although the Basque Country and Galicia proposed their statutes, domestic politics in the state in the 1930s did not allow the statutes to be implemented in practice (Rosenberg, 1997, p. 28).

Pursuant to Article 147 (2) of the Constitution, the Statute must also establish the institutional framework of the Community, that is to say, its individual bodies. The system of bodies that each region can create according to itself is regulated by Art. 152 para. 1 of the Constitution. However, absolute freedom does not apply here, as the communities must comply with the provisions of the four prescribed bodies. These are the Legislative Assembly (Asablea Legislativa), the Government Council (Consejo de Gobierno), the President of the Autonomous Community (Presidente) and, finally, the Tribunal Superior de Justicia. The Constitution stipulates the obligation to establish such a body but does not specify its name. Therefore, in some areas, a body with legislative powers is called differently. In the Extremadura region, this body is called the 'Assembly', in the Basque Country or Andalusia it is called the 'Parliament', and in the region of Asturias, it is called the 'Cortes' (Domin, 2013). Here we have communities that have a certain degree of freedom in creating their bodies. But it also applies here that communities must establish a body that conflicts with the Constitution. An example of a Community body that is outside the mandatory framework of the bodies provided for in the Statute is the Economic and Social Council (Consejo económico y social) (Domin, 2013, p. 49). For example, it is established in the Valencia and Madrid area.

The relationship between the central government and regional governments has changed throughout history. At present, it is regulated in individual statutes. More specifically, the statutes define the competences of the communities, which are taken over from the central government. These competences are then exercised by the above-mentioned bodies. The Constitution offers a definition of the competences of the communities. It defines several types of competences: exclusive competences of the state, exclusive competences of the communities and shared competences of the 
state and the communities. The exclusive competences of the state include the issue of citizenship, migration, as well as state defence, foreign policy, customs duties, criminal and labour legislation, etc. The question of exclusive Community competences and shared competences seems more complex. In principle, however, it can be said that the Constitution regulates these competences only within a framework. It, therefore, only offers a framework of competences from which individual regions can choose. The choice of individual competences is set out in the statutes of each community. The competences that the community does not take over are automatically left to the central government. This is governed by Article 149 (3) of the Constitution. The competences of the communities may include, for example, the administration of rail and road transport, the question of the organization of Community bodies, or tourism in the territory of the Community (López Guerra et al., 2010). At the same time, the exclusive jurisdiction of the Autonomous Communities includes local civil law, agriculture, domestic production, social welfare, housing construction, culture, etc. (Rosenberg, 1997). The calculation of the third category, the shared competences between the state and the community, is slightly problematic. The Constitution does not offer an exact calculation. In order to be able to name the shared competences, we must make a comparison between Article 148 (1), which defines the exclusive competences of the State, and Article 149 (1), which defines the competences of the Communities. The degree of state participation in individual competencies may vary (Domin, 2013, p. 49). In the event of a conflict between Community law and the law of the State, the law of the State shall prevail (Rosenberg, 1997, p. 31).

It is also important to mention Article 155 of the Spanish Constitution. This article enshrines the right of the central government to use means which compel the Autonomous Community to comply, respectively, not to violate the obligations arising from the Constitution or any other law. In such a case, the use of force would also be accepted. We can state that the acquisition of statutes after the fall of the Franco dictatorship had three different processes - fast, medium and slow. The fastest statutes were adopted and recognized in the so-called historical regions. Historical regions are granted wide legitimacy of their requirements and powers. Other regions did not see the adoption of autonomous status until later.

Spain has arranged autonomous regions according to different lengths of acquisition of their regional autonomy: 
- Historical regions and special conditions - the Basque Country, Galicia, Catalonia, Navarra

- Regions with a rapid pace of autonomy - Andalusia

- Regions with a moderate course of gaining autonomy - Valencia, the Canary Islands, the Balearic Islands, Extremadura, Cantabria, Castile La Mancha, La Rioja, Madrid, Murcia

- Regions with a slow process of gaining autonomy - Aragón, Astúrias.

\section{THE BASQUE REGION}

The Basque Autonomous Community (Basque Autonomous Community, Comunidad Autónoma Vasca in Spanish, Euskal Autonomia Erkidegoa) lies in the north of Spain. It connects the country with the Bay of Biscay, respectively the Cantabrian Sea. The Basque province of Gipúzcoa borders France, but their common border is no longer than $20 \mathrm{~km}$. The Basque Country is one of the smallest regions in Spain. Nevertheless, it is very strong economically. It consists of three provinces - Álava, Vizcaya and Gipúzcoa (Arab, Biscay, Gipuzkoa). The capital of the Basque Country is the city of Vitoria (after the Basque Gateiz) and is located in the province of Álvara. The population of this province consists mainly of the Basques, who consider their language - Basque (also called Euskara or Eurskera) as part of their unique identity (Cancela-Kieffer, 2018). Basque, together with Castilian, is the official language of the Community. This fact is also confirmed by the Statute of Autonomy of the Basque Country of 1979. However, the Basques do not live only within the Basque Country. The Basques can be found east of the Basque region, in a neighbouring region called Navarra. The border between Spain and France does not reflect an ethnic, respectively linguistic distribution of the population. A large group of the Basques also lives in the territory of France, specifically in the provinces of Lapurdi, Nafarroa Beherea and Zuberoa.

As we have already said, the political-administrative borders of the Basque Country cannot be equated with imaginary linguistic borders. Basque is considered to be the mother tongue not only of the inhabitants of the Basque Country and the French border provinces, but also of the inhabitants of the northern parts of the neighbouring autonomous region called Navarra. Language is a kind of unifying element and the Basques are very proud of it (Miháliková, 1998). 
The Basque Country covers a relatively small area - covering about 7,000 $\mathrm{km} 2$. It is home to more than 2,188,000 inhabitants (in 2019), which makes up $4.7 \%$ of the entire population of Spain (European Commission, n.d.).

The status of Basque autonomy came into force in 1979, although attempts to achieve autonomy were known in the Basque Country as early as 1936. Since 1979, the competences of the Basque Country as a historical region have been broader than in other regions of Spain. The Basque Country has gained independence in the management of education, the judiciary, health, industry, tourism and agriculture.

\section{THE CATALONIA REGION}

Catalonia (English Catalonia, Spanish Cataluña, Catalan, Catalunya) is one of the 17 autonomous communities that compose the Kingdom of Spain. It is located in the northeast of the Iberian Peninsula on the Mediterranean coast and borders France and Andorra. Catalonia is a coastal region with a significant location that has made it a trading hub for centuries. More than 7.5 million people live here (in 2018) and it is an interesting tourist destination for millions of other people. It is the second most populous region of Spain - 16\% of the country's population lives in Catalonia. Catalonia covers approximately 32,000 km2 (Cancela-Kieffer, 2018). The largest city and at the same time the 'heart' of Catalonia is Barcelona. The Autonomous Community of Catalonia consists of four provinces: Girona, Barcelona, Tarragona and Lleida (Baar, 2002, p. 67).

From the beginning of the 21st century, separatist tendencies began to gain momentum in Catalonia. Today, the region is often mentioned in particular connection with political instability, efforts to achieve independence and conflicts with the central government in Madrid. Now, we will focus on Catalan separatism and the cultural, political and economic development of this autonomous region.

\section{COMPARISON OF SEPARATIST TENDENCIES OF THE BASQUE COUNTRY AND CATALONIA AND PREDICTIONS OF FURTHER DEVELOPMENT}

The separatist tendencies of both the Basque Country and Catalonia are similar in many respects, but there are some differences. In the following chapter, we will use a comparative method to present the basic differences 
between the separatist tendencies of both autonomous communities and make three predictions of the future development of their separatist efforts.

\section{A brief comparison of Basque and Catalan separatism}

The difference between Basque and Catalan separatism was captured by Pablo Simon, a professor of political science at the University of Madrid. He argues that the interests of the two regions are very different. One region wants to protect what it has achieved, and the other wants more (CancelaKieffer, 2018).

The emergence of both nationalist movements dates back to the end of the 19th century. Their origin was connected to socio-economic changes in the state and Spain's efforts to centralise as much as possible. Both Catalonia and the Basque Country felt damaged by the situation. Movements and political parties representing the demands of dissatisfied social groups began to emerge. However, the programmatic focus of both nationalisms was different (Miháliková, 1998).

A common feature of both separatist movements is that they cite their different language, culture and historical experience from the rest of Spain as one of the main arguments for gaining independence. Another existing different feature is the Catalan separatists' arguments regarding namely the economic issues and taxes. Basque separatism is not based on economic arguments, as the Basque Country is granted broad autonomy in fiscal policy. On the other hand, Catalan separatism is based on economic arguments, i.e., the outflow of Catalan funds through the treasury to less prosperous regions. At the same time, only a small part of the funding is being returned to Catalonia, which supports efforts to gain independence. To sum it up, although the two Autonomous Communities are economically very prosperous and industrially developed, the presence of arguments concerning the economy is different in the two communities. In other words, the Basques do not consider their strong economy to be an important argument for the emergence of an independent state. Catalan separatism, on the other hand, has its roots in economic causes.

A common feature is the existence of political parties representing the efforts to create an independent state. It is a traditional PNV party in the Basque Country, but there are more of these parties in Catalonia. The parties supporting the independence of both Autonomous Communities are part of the Cortes Generales. 
However, we see a significant difference in the way in which the regions want to achieve their goal. The terrorist group ETA has been fighting for Basque independence for almost 60 years, killing hundreds of people. No similar organization has been formed in Catalonia. The struggle for independence is represented only by political parties and no armed attacks by Catalonia have yet taken place (De la Calle, 2015).

Interestingly, in 1989, Basque nationalism was visible as more aggressive, more inclined to separatism, and seeking independence from Spain. On the contrary, Catalan nationalism seemed more moderate at the time. Its goal was to gain as much independence as possible, but within Spain (Miháliková, 1998). Today we can see that the situation has changed. Basque separatism seemed to freeze, the Catalan one awoke. The Basque Country made Spain's political life more difficult, especially in the 1970s, when the ETA's attacks were extremely frequent and neither side was open to dialogue. The Catalan separatist tendencies have brought intense tensions and instability to Spain since 2010. Following the independence referendum on 1 October 2017, stability has deteriorated further, and the relationship between Barcelona and Madrid has deteriorated significantly. In order to calm the situation in Spain, world leaders commented on the national situation, who supported the unity of Spain but rejected the harsh intervention of the Spanish Guardia Civil police during the referendum in 2017 (Cancela-Kieffer, 2018).

In the past, while the ETA was fully operational, the withdrawal of the central government in favour of an independent Basque Country was out of the question. It would be a clear signal to other regions in Spain and around the world that violence and terrorism are the best way to achieve their goals. Today, in 2020, after the official and final dissolution of the ETA, however, Basque nationalism has declined. The only reminders of the ETA's activities are the victims of their assassinations, its former members and prisoners, who are gradually being released (Cancela-Kieffer, 2018).

\section{Predictions about the development of the Basque and Catalan issues}

The aim of the work is to explain the predictions about the development of the Basque and Catalan issues. In the following part, we will offer an evaluation through three different scenarios of further development in the Basque Country and Catalonia.

To begin reflecting on the future development of the Basque Country and Catalonia, it is important to raise the question of whether an entity 
separated from Spain would at all meet the attributes of the State. The attributes of a state are certain criteria that a territorial-political entity must meet in order to be considered a legitimate state. In most of the literature, we can meet with the three main attributes of the state, which were first defined by Jellinek in 1906. They are a permanent population, a defined territory and a sovereign state power, and it is true that these attributes must be met simultaneously. The generally accepted document containing the definition of the state is the Montevideo Convention from 1933. The Montevideo Convention, which defines the fundamental rights and obligations of the state, contains, in addition to the three attributes mentioned, the fourth - the ability to enter into relations with other states (Krejčí, 2014, p. 72). However, some authors do not identify with the fourth attribute and call it controversial. The first three attributes are directly related to the creation of the state or are inevitable for its emergence. However, the ability to enter into relations with other states is not directly related to the establishment of the state. In the following predictions of development, we will try to answer the question of whether an independent Basque Country and Catalonia would meet the criteria of statehood.

The first scenario that could come true is to maintain the status quo. The second scenario would be a deepening of autonomy, and the third scenario is the emergence of an independent Basque Country or Catalonia. The third option raises a number of questions, and we will try to find answers to some of them in the next part of the work.

As we have already said, the first scenario assumed the situation where the Basque Country and Catalonia maintain the status quo. This would mean that both the Basque Country and Catalonia would remain the autonomous communities of the Kingdom of Spain without enforcing any change. In the Basque Country, separatist tendencies would remain relatively subdued, as they are today. In order to maintain the status quo in the Basque Country, no new organization should be mobilized to continue the ETA's activities. The ruling party PNV would not make any radical personnel changes and would continue to refer to dialogue against violence. However, maintaining the status quo would mean another period of instability, demonstrations and tensions between Catalonia and the central government for Catalonia. Reluctance to act can be observed from both sides. Proposals for a new fiscal pact to increase Catalonia's fiscal autonomy would have to be rejected by the central government. At the same time, ties and trials would continue with several Catalan pro-separatism policies, which the public strongly rejects. We think that maintaining the status quo 
would benefit the relationship between Spain and the Basque Country. However, in the case of the Spanish-Catalan relationship, maintaining the status quo would have the opposite effect. Their extremely tense relationship needs space for dialogue. At this moment, however, neither side is considering concessions, and political leaders have not negotiated for a long time. We consider this scenario, i.e., maintaining the status quo, to be the most likely for the Basque Country (Krejčí, 2014, p. 62).

The second possible scenario of development is the deepening of the autonomy of the mentioned autonomous communities. This would require a change in the status of autonomy. Although the Basque Country is more fiscally autonomous than Catalonia, there are still areas in the Basque Country that could escape the control of the central government. Catalonia would welcome an increase in fiscal autonomy by adopting a new fiscal pact, which Madrid has rejected in the past. Catalonia would thus be given greater powers to administer the taxes levied on its territory. It would not pay more into the treasury than it gets back, and thus the fiscal deficit would be reduced. This scenario seems to us to be the most likely to resolve the Catalan question (Rosenberg, 1997).

The third assumed development scenario is the fulfilment of independents requirements, the creation of an independent Basque Country and Catalonia. However, it should be recalled that in the event of a declaration of unilateral independence leading to an Art Nouveau, both regions would have to face a number of challenges, which we will try to approach (Giertl, 2012).

From the point of view of the legality of the declaration of independence, there are only two possibilities - independence will be achieved legally or illegally. If the Basque Country or Catalonia were to achieve independence in a legal and legitimate way, they would have to find an appropriate legal framework according to which the creation of their independent states would be feasible. We assume that a necessary step would be to change the Spanish Constitution. However, the two longest-strong Spanish parties, the PP and the PSOE, have strongly rejected any attempt to undermine Spain's territorial integrity. Their common position is that they will not support separatist tendencies. Therefore, we do not expect them to support a change in the Constitution or an independence referendum. Therefore, if the government were to make changes to the Constitution and hold an independence referendum, the regional pro-parliamentary parties would have to succeed in the national parliamentary elections and create a parliamentary majority. Later, the already mentioned amendment of the Constitution would be 
necessary. Such an act would require the consent of a majority of the two Chambers of the Cortes Generales (Cancela-Kieffer, 2018).

On the other hand, the declaration of independence could also take place in an illegal and unconstitutional way, as was the case in Catalonia in October 2017. Catalonia was not supported by any state. If the secession did take place, the newly created state would find itself in international isolation. The recognition of the state by other states is important for the existence of the state, especially those at the top of the imaginary pyramid of power (López Guerra et al., 2010, pp. 200-202).

Following the creation of a new Basque or Catalan state through secession from Spain, this new state would necessarily have to resolve a number of key issues important to the very survival of the new state. The first key issue is the relationship between the newly created state and the European Union (EU). As for Catalonia, it expressed its desire to become an EU Member State after independence in 2012 during the independence referendum. The question of the referendum was 'Do you want Catalonia to become a new state within the European Union?'. These desires have not changed to this day and were revived in 2017 during the independence referendum. However, the then President of the European Commission, Jean- Claude Junker, refuted Catalonia's ideas, arguing that the newly formed state must re-submit to all pre-EU procedures (López Guerra et al., 2010, p. 213). The new Basque or Catalan Republic would therefore not automatically become a member of the EU, as Catalonia in particularly had hoped, but would have to re-join it. This would mean that both regions would have to meet all the requirements related to the granting of candidate status. In considering for a given state to become a member of the EU, it would have to undergo new accession negotiations and fulfil the accession, the so-called Copenhagen criteria. At the same time, the admission of a new member to the EU would have to be approved by all EU Member States, as discussed in Article 49 of the EU Treaty (López Guerra et al., 2010, p. 219). We assume that this step could be problematic. Not only Spain but also the other Member States could, by their consent, set a precedent to which many other separatist regions could begin to refer. Such a step could start the socalled snow globe effect.

Another problem for the newly created state would be its membership in NATO. After separation from Spain, the newly formed state would not belong to NATO. Even if it wishes to become a member, the accession of a new member to NATO is subject to the consent of all member states. 
Expressing support for the Basque Country or Catalonia could, as in the case of the EU, set a precedent and start the so-called snow globe effect.

As we have already said, the newly created independent Basque Country or Catalonia would not be among the EU Member States once it was created. Declaring their independence would create a complicated situation regarding the free movement of persons, goods, services and capital, which is one of the EU's main Four freedoms. The borders of the new state would become highly guarded because the state would not even belong to the Schengen area. All this would also have a huge impact on the movement of labour and the economy itself, resulting in huge economic downturns. Marinzel (2014) predicts that there would be a boycott of Basque and Catalan products on the Spanish market. In addition to the disruption of trade relations with Spain, both regions should also expect a decline in international export markets. Catalonia exports to the many EU Member States and the loss of EU membership would require customs duties. This would make exports more expensive and likely fall (Marinzel, 2014). In addition, as Spain is part of the Economic and Monetary Union, both the Basque Country and Catalonia would no longer be entitled to the euro after the separation. Such difficult obstacles would harm the Basque and Catalan economies. An example is a period at the end of 2017, which was marked by instability and a referendum on Catalonia's independence. As we have mentioned, almost 2,000 companies have relocated their headquarters from Catalonia to other Autonomous Communities, which is only a small percentage of the problems that the newly created state would have to face. Both Autonomous Communities would have to face an economic slowdown, as the Bank of Spain suggests (Benítez-Aurioles, 2019).

Public opinion polls in Catalonia have long shown a strong polarization of society. The society is divided into supporters of independence and supporters of Catalonia staying within Spain. The society is polarized almost exactly in two halves. If Catalonia continued to fight for its independence, one of the tasks would be to increase the percentage of supporters of this idea, both in the society and in the Generalitat.

Another challenge for the newly formed Catalonia or Basque Country would be to gain the recognition of other states. According to Giertl, the act of recognition of the State does not affect the very existence of the State. This means that even an unrecognized state is a legally responsible entity under international law. However, this does not call into question the importance of recognition. A state that has not been recognized by the international community finds itself in isolation and has very limited opportunities for 
self-realization (Giertl, 2012, p. 33). Vintró, an expert in constitutional law at the University of Barcelona, argues that before a state can get to the issue of its international recognition, it must ensure that its state power is effective and recognized (Roden, 2017).

So, at the end, we believe that the Spanish Government will prioritize the power of argument and diplomacy over the argument of power.

\section{CONCLUSION}

In the presented text, we have tried to evaluate what Basque and Catalan separatism have in common and how they are different. The most significant difference is their current interests. Basque separatism is subdued, mainly due to the dissolution of the Basque terrorist organization ETA in 2018. It seeks to maintain the status quo. However, during 60 years of efforts to achieve its goal, it has killed hundreds of people in its attacks. On the other hand, Catalan separatism is not primarily violent, but also emotionally embedded across various parts of its society, similarly to the Catalan sovereignist movement. It is represented mostly by legal political parties and no terrorist organizations. In the case of Catalonia, we have witnessed instability on the political scene and tensions between Barcelona and Madrid since 2010, in contrast to Basque separatism, which was most active in the 1970s. Another important difference between the two separatist tendencies is the presence of economic arguments. While the Basque Country is satisfied with the current fiscal policy conditions, Catalonia feels aggravated and its arguments for independence are based on economic considerations. In the third chapter, we also offer predictions of the development of Basque and Catalan separatism. We have outlined three possible scenarios: maintaining the status quo, deepening autonomy, and creating an independent state. Based on previous analyses, we believe that in the case of the Basque Country, the most likely scenario is a status quo. The Catalan question, in turn, could be resolved by deepening its autonomous powers.

To sum up, Basque and Catalan separatism is not based on the same values. Identity plays the most important role in Basque separatism, with the economic causes currently absent. On the other hand, Catalan separatism is built primarily on the political and economic reasons. Cultural differences as a cause of separatism are, of course, present, but in the case of Catalonia, they are less significant.

We conclude that arguing the nation's right to self-determination is more legitimate in the case of Catalonia than in the case of the Basque Country 
because Catalonia's internal right to self-determination is not fulfilled to the same extent as in the Basque Country. But we should argue that the legality of the right to self-determination is also an international legal category. In international legal terms, any such notions of self-determination would require approval from the highest national authority. In this comparison, this is due to fiscal policy, which is currently set more in favour of the Basque Country, and a sense of responsibility in Catalonia seems justified.

\section{REFERENCES}

Baar, V. (2002). Národy na prahu 21. století. Emancipace nebo nacionalismus? [Nations on the threshold of the 21st century. Emancipation or nationalism?]. Šenov u Ostravy, Tilia.

Benítez-Aurioles, B. (2019). Transition costs and economic effects of the sovereignty process in Catalonia, Regional Science Policy E Practice, 11(5), pp. 821-832.

Boyle, K. \& Englebert, P. (2006, March). The Primacy of Politics in Separatist Dynamics, retrived from https://cega.berkeley.edu/assets/miscellaneous _files/wgape/10_Englebert.pdf. Accessed 6 January 2021.

Cambridge Dictionary. (n.d.) Separatism, retrieved from https:// dictionary. cambridge.org/dictionary/english/separatism. Accessed 5 January 2021.

Cancela-Kieffer, M. (2018, April 30). Analysis: Why Catalan and Basque separatists are going different ways. The Local, retrieved from https:/ / www.thelocal.es/20180430/analysis-why-catalan-and-basqueseparatists-are-going-different-ways. Accessed 5 January 2021.

Čajka, P., Terem, P., Rýsová, L. \& Ištok, R. (2010). Politická Geografia [Political geography]. Banská Bystrica, FPVaMV UMB.

Červenáková, M. (2013). Vojenské a polovojenské separatistické hnutia v Afrike a ich aktivity $v$ kontexte porušovania princípov a noriem medzinárodného humanitárneho práva [Military and paramilitary separatist movements in Africa and their activities in the context of violations of the principles and standards of international humanitarian law]. Banská Bystrica, Univerzita Mateja Bela, Právnická fakulta.

De la Calle, L. (2015). Nationalist Violence in Postwar Europe. Cambridge, Cambridge University Press.

Domin, M. (2013, 25 June). Španielske Autonómne Spoločenstvá [Spanish Autonomous Communities], retrieved from https://www.academia. 
edu/18381919/\%C5\%A0panielske_auton\%C3\%B3mne_spolo\%C4\%8D enstv\%C3\%A1_Spanish_Autonomous_Communities. Accessed 5 January 2021.

European Commission. (n.d). Basque Country, retrieved from https:/ / ec.europa.eu/growth/tools-databases/regional-innovationmonitor/base-profile/basque-country. Accessed 6 January 2021.

Giertl, A. (2012). Štát in statu nascendi [State in the state of education], in: D. Lantajová (Ed.), Právo národov na sebaurčenie v kontexte moderného medzinárodného práva (pp. 17-38). Trnava: Trnavská univerzita v Trnave, Právnická fakulta.

López Guerra, L., Espín, E., García Morillo, J., Pérez Tremps, P. \& Satrústegui, M. (2010). Derecho constitucional. Volumen II. Los poderes del Estado. Organización territorial del Estado [Constitutional law. Volume II. The power of the state. Territorial organization of the State]. Valencia, Tirant Lo Blanch.

Hruboň, A. (2020). Naci(onali)zmy v nás. Bratislava, Paradigma Publishing.

Chalupa, J. (2009). Diktátor a prosperita: Francisco Franco a španělský "hospodářský zázrak" [Dictator and Prosperity: Francisco Franco and the Spanish “Economic Miracle"], Historický obzor, 20(1-2), pp. 14-25.

Ištok, R. (2003). Politická geografia a geopolitika [Political geography and geopolitics]. Prešov, Prešovská univerzita v Prešove.

Ivančík, R., \& Nečas, P. (2012). International Security from the View of Postmodern Conflicts on African Continent. Rzeszów, Publishing house Amelia.

Krejčí, O. (2014). Medzinárodní politika [International Politics]. Praha, Ekopress.

Lněnička, L. (2011). Vybrané texty z politické geografie [Selected texts from political geography]. Brno, Masarykova univerzita v Brne, Pedagogická fakulta.

Marinzel, A. (2014). Catalonia: The Quest for Independence from Spain, retrieved from https://collected.jcu.edu/cgi/viewcontent.cgi?article= 1039\&context=honorspapers. Accessed 8 January 2021.

Mesárová, N. (2012). Separatizmus v Španielsku: Baskicko a Katalánsko [Separatism in Spain: the Basque Country and Catalonia]. Banská Bystrica, Diplomová práca.

Miháliková, S. (1998). Politické a právne aspekty postavenia menšín vo vybraných krajinách západnej a juhozápadnej [Political and legal aspects 
of the position of minorities in selected western and southwestern countries], Parlamentný kuriér, 6(50), pp. 11-13.

Rosenberg, V. (1997). Systém autonómnych oblastí v Španielsku [The system of autonomous regions in Spain], Medzinárodné otázky, 6(2-3), pp. 20-27.

Roden, L. (2017, October 10). This is what could happen if Catalonia declares independence. The Local, retrieved from https:/ / www.thelocal.es/2017 1010/this-is-what-could-happen-if-catalonia-declares-independence. Accessed 9 January 2021.

Ryabinin, Y. (2017). The basic causes of the temporary separatism, Journal of Geography, Politics and Society, 7(1), pp. 5-9.

Schaeffer, R.K. (2008). Secession and Separatism, in: L. Kurtz (Ed.), Encyclopaedia of Violence, Peace, E Conflict (pp. 1887-1892). Fairfax, Elsevier.

Žaloudek, K. (2004). Encyklopedie politiky. Praha, Libri. 